\title{
GENDER IN PROSE AS ONE OF THE ASPECTS OF THE ADYGHE ETHNIC CONSCIOUSNESS (FIRST HALF OF THE 20TH CENTURY)
}

\author{
(c) Fatimet N. Khuako \\ Maykop State Technological University, \\ Maykop, Republic of Adygea, Russian Federation \\ fatimah2@mail.ru
}

We consider the image of a woman and its reflection in literature using examples of the work of Adyghe authors of the first half of the 20th century (H. Teuchezha, J. Tlyusten, A. Evtykh). The author turns to regional North Caucasian scientific works affecting gender issues, argues the idea of the peculiarity of this line among the Adyghe with their ethnic consciousness. It is concluded that there is little coverage of the image of a woman in literary criticism, especially in an ethnic (Adyghe) context. The traditionality of the Adyghe ethnic group is analyzed in detail; the problem of discrimination in relation to the Adyghe woman in the family; the characterological series of the female image both in society and in the family, and in works: hard work, needlework, etc., as well as the ability to survive in a difficult situation. Based on a number of traits of a female character both in the ethnic group and in the works there is the assertion that it is permissible to consider the Adyghe woman's right to positively influence conflict situations in society as evidence of the absence of any discrimination that could directly and fruitfully influence the development of centuries of ethnic consciousness..

Key words: gender, woman as an image, Adyghe, prose, ethnic group, first half of the 20th century.

[Ф.Н. Хуако Гендер в прозе как один из аспектов адыгского этносознания (первая половина XX в.)] Рассматривается образ женщины и его отображение в литературе на примерах творчества адыгских авторов первой половины XX века (X. Теучежа, Ю. Тлюстена, А. Евтыха). Автор обращается к региональным северокавказским научным трудам, затрагивающим гендерную тематику, аргументируется идея о своеобычии этой линии у адыгов с их этническим сознанием. Делается вывод о малом освещении образа женщины в литературоведении, тем более, - в этническом (адыгском) контексте. Подробно анализируется традиционность адыгского этноса; проблема дискриминации применительно к адыгской женщине в семье; характерологический ряд женского образа как в обществе и в семье, так и в произведениях: трудолюбие, рукоделие и т.д., а также умение выстоять в трудной ситуации. Выводом по ряду черт женского характера как в этносе, так и в рассматриваемых произведениях является утверждение о том, что именно право адыгской женщины позитивно влиять на конфоликтные ситуации в социуме допустимо рассматривать как доказательство отсутствия какой-либо дискриминации, которое напрямую и плодотворно могло воздействовать на вырабатывание векового этнического сознания.

Ключевые слова: гендер, женщина как образ, адыг, проза, этнос, первая половина XX в.

Fatimet N. Khuako - Ph.D. (Advanced Doctorate) in Philology, Professor, Maykop State Technological University, Maykop, Republic of Adygea, Russian Federation.

Хуако Фатимет Нальбиевна - доктор филологических наук, профессор, Майкопский государственный технологический университет, г. Майкоп, Республика Адыгея, Российская Федерация.

Gender issues today very organically occupy a significant place in the research. Parallels can be drawn here with Russian critical thought. In particular, the pre-revolutionary literary Russian theorist A. Grigoriev in his classic edition Literary Criticism (Moscow, 1967) often and productively mentions the female image as an object of reproduction on the pages of contemporary writers. For example, in the analysis of "Grief from Wit" by A. Griboedov, Sofia, Anfisa Nilovna and others, as well as in the works of N. Dobrolyubov, A. Pushkin, L. Tolstoy and other pre-revolutionary creators, are praised, condemned or opposed. There was a place to be with a critic, and an attempt to classify female characters. According to A. Grigoriev, 
analyzing the image of Sophia next to Chatsky (A. S. Griboedov, "Woe from Wit"), women can be classified into two types of literary texts: 1) endowed with energy, sharply beautiful and attached to a higher ideal ; 2) deprived of giftedness, slavishly following their beloved [3, p. 506]. Such a distinction allows the theoretician to very thoroughly carry out a comparative analysis of the images of Sophia and Desdemona on their life path, next to the men accompanying them.

In the theory of Russian literature of the Soviet era (for example, in the manuals of L.I. Timofeev or G.L. Abramovich and others), there are practically no paragraphs that distinguish a woman as an independent artistic character. In the considered classic seven-volume edition of M.M. Bakhtin's literary criticism also shows a virtually complete lack of appeal to this subject. Only once, there was a condemning note when censured by one of the foreign authors (F. Rabelais in his satirical novel of the 16th century "Gargantua and Pantagruel") in his expressive grotesque reproduction, when the mouth of the storyteller Panurg describes how to build walls around Paris using parts female body. A noticeably more frequent interest in women as a worthy and entertaining image is among foreign literary theorists. In particular, in the works of $A$. Kompanion such a heroine is periodically analyzed in the course of consideration of the problems of author's intention or retrospective reproductions, in conditional disputes with opponents and with their own plot-analytical assessments. Therefore, we will turn to the work of this French theoretician more than once in our work.

Gender interest today can be described not only as a world trend, but also find reflection in the North Caucasian scientific works. In this case, it can be said that it is presented in the North Caucasian literature even more peculiarly, since this territory has its own cultural identity of the ethnos. Throughout history, the Adyghe saint code of honour "adyghe habze" bears one of its covenants that is successfully expressed in the Adyghe proverb: "For the sake of well-being, women bring great difficulties" [2, p. 132]. A certain perception of a woman was recognized as a significant component of the Adyghe ethnic consciousness. If even a female shadow engaged in her own affairs is indicated in the field of vision of a male group, representatives of the stronger sex get distracted, pay attention to her and begin to identify the causes of her likely anxiety. However, the interest expressed by modern scholars expressed above is noticeable mainly in sociological (for example, A.A. Bezrukov) or historical (for example, M.A. Tekuev) writings on the place and status of women in the Adyghe historical society. Also, as applied to literary criticism, research on gender issues is possible in works devoted to the so-called "female prose" or "female poetry" (that is, works written by female writers or poets). Nevertheless, the topic of interest to us is a woman as an image on a page of a literary text (and with reference to Adyghe authors of the middle of the last century) which is practically not covered in today's science. Therefore, in the current article we chose to cover gender issues in the North Caucasian (in particular, Adyghe) ethnic identity with examples from the texts of the last century.

Since our preferred humanitarian topic is at the junction of literary, sociological and historical sciences, the methods in this case are traditional interdisciplinary moves. In particular, analysis, synthesis, comparison, comparison and the possibility of results. At the same time, as applied directly to ethnic issues, we use the methodology proposed in modern science as "ethnomethodology", i.e. the so-called "study of knowledge of common sense" [7, p. 23]. This helps us, based on the identification of a number of real components of the Adyghe woman's life as an active carrier of the Adyghe ethnic consciousness, to trace the reproduction of this component in Soviet prose of the first half of the 20th century (on the examples of texts by $\mathrm{Y}$. Tlyusten, A. Evtykh and H. Teuchez).

Adyghe society today has a rich civilizational experience of self-presentation to humankind as a mandatory traditional construct. In a mobile and constantly transforming world space, the optimal and really conditional naming of a number of features traditionally inherent in a particular ethnic group will provide the likelihood of the same optimal definition of step- 
by-step security instructions. The tradition in society in this case is based on the field of chronological custom, including; moreover, the gender pattern is woven from the relationships existing in society. There is also such a component as living in an appropriate environment, more often physical, the so-called practice of being, information about which is chronically available in ethnographic materials. But here, too, the traditionality of culture, acting and continues to represent such roles (as A.A. Bezrukova says), such as: "a) translation of experience; b) the type of social memory; c) a way of socializing a person "[2, p. 131].

In the ethnosphere analyzed here, traditionalism is actually fixed and continues to function. Characterological features inherent in such a society were very tangibly and continuously preserved in the Caucasian space. In fact, Adygs relatively recently, only with the advent of planetary globalization began to try to go beyond the boundaries of traditionality, in fact, national being was kept intact for a long time. At the same time, it is obvious that the grandiose part when fulfilling long-term traditional roles by an ethnos is related specifically to a woman.

There is also a problem of gender discrimination in this field. In accordance with the cited from A.A. Hofstede's armless theory, "differences in sexual roles depend on the degree of masculinity or femininity of a particular culture" [2, p. 131]. At the same time, one can call the statement that "the kindred community and its female fastening principle are turned into the past and inside of collective life, and the male production initiative is turned into the future and outside" [7, p. 26]. Gender differentiation by sexes, sometimes giving rise to an uneven division of public missions, was also possible in the Adyghe traditional society. There is an extraordinary significance of the female presence in family rituals, in the role of a woman to save the flame in a home oven.

In general, the literature of both pre-revolutionary and Soviet times often traced the tendency to confer upon women a certain discriminated function. This could not remain out of sight of the artistic authors of that period. At the same time, no writer is capable of evading into another locality, holding off, igniting something that is not related to social problems, to chronicles of events. As a literary critic of the beginning of the last century B.M. Eichenbaum, "Not being a writer or journalist, he also vigilantly follows every movement of public and literary life and reacts to everything. It seems that he does not allow the thought that something important passed without his participation or intervention" [12, p. 79]. Further: "When the question of female emancipation is raised, he writes the novel "Family happiness" [12, p. 80]. Similarly, the heroes of later, already Adyghe authors could not remain indifferent to images of their compatriots (not always positive). A storyteller at $Y$. Tlyusten describes well such a conditional, a little scary image ("Girl's Dawns"), watching the girls about to "frolic": "If to frolic, when you are still a maid. When she gets married it is as if she cuts off the past, as if she is taken prisoner" [9, p. 22]. Although we note here that, the potential bride herself had the right to select the groom from a number of suitors who were passing before her eyes. But, indeed, a certain, relatively speaking, family endurance noted in the citation of the writer (strict behavior of the daughter-in-law, her fear of touching her mother-in-law, lack of the right to make contact with her mother-in-law, etc.) had and still has a place in the Adyghe family.

Another thesis of an elderly woman in the same work of $Y$. Tlyusten: "A woman was born to obey her husband, to be faithful to him as a slave and mother of children" [9, p. 27]. However, there was a confrontation of such a position. The young teacher argues with her, insisting that the woman pushing her learn to read herself in order to become an invincible debater. In serious, often scientific thought, the socio-legal status of Caucasian women is also presented as a kind of discriminatory, most infringed, than that of neighboring peoples. However, such an approach is not sufficiently substantiated, since, on ritual-folklore material, the predominance and obvious dominance of the fairer sex can be seen in the installation and in the assembly of social-family correlation. Moreover, this is a kind of counterbalance to the stronger sex in building wider (already at the collective level) structures that fulfill certain, "relatively speaking, production goals (war, work, hunting, etc.)" [7, p. 26]. As R.A. Hanahu 
says about this, "The head of the family is always a husband. A wife submits to her husband, but is not, as is sometimes considered to be his "slave." In particular, the Adyghe have always considered it a shame if a man uses physical violence against a woman. A woman was not "enslaved", but as if "separated" from him within the framework of such a "separate existence" she enjoyed certain freedom and privileges"[10, p. 35]. As noted by A.A. Bezrukova, emphasizing the almost complete absence of women in the people's Councils of Elders, which is justified, as applied to ethnic heroine, in the national epic of Narta, by the presence of Setenai at such fateful meetings: "she (Setenai) surpasses the Khase (Council) elders with her wisdom and saves them from the death sentence of her husband. No matter how Orzamage and Sausyryko are well armed, without the advice of Setenai they are powerless"[2, p. 133].

Along with this, there were social trends of presenting a mountain woman in the field of society, where there were signs of her powerful influence. Here we can mention the importance of a mountain woman in the process of instilling knowledge, abilities and skills between generations, building her experience of a loyal and adequate young ethnic representative. It is noticeable that the power of influence mentioned above included by no means bare rights to membership in political or economic processes. There was an explicit respect for the "weaker sex" in society in affectionate and complimentary appeals (such as "girl", "dear", "daughter" or "our mother", "our princess", "our mistress", etc.), which is constantly, repeatedly and variously manifested in the pages of the texts of $\mathrm{H}$. Teuchez, A. Evtykh and Y. Tlyusten that we study in this work, reproducing the existing relationships in the Adyghe society with an illustration of them through such appeals. Consequently, the family status of the Adyghe woman was mistakenly recognized as discriminatory, since she was honored in a dignified manner, and she owned real protective tools that made it possible to patronize the injured representatives of the stronger sex, sometimes standing on the verge of death.

Among the protective mechanisms that we cite here, there is the strongest and most frequent image of the nanny in fiction (both in Russian classical literature and in Adyghe one). Such a gender concept as a nanny can be considered traditionally frequent in the literary texts, since they took part in the upbringing and formation of most of the domestic prerevolutionary authors. For example, in Russian classical prose, the image of the nanny by $\mathrm{F}$. M. Dostoevsky is particularly impressive; his most affectionate childhood impressions are generated by these two main women in his life - mother and "nanny". The Russian author is sure that directly thanks to the nanny he was able to plunge into the literature, since such a storyteller gathered daily the whole family in anticipation of the next incendiary story. Such animated and inextinguishable memories often emerge and are active in the famous novels of F. Dostoevsky. First of all, one of the Adyghe writers who carefully looked at the woman working at home, caring for the child, was Khabib Teuchezh (for example, the story "The Nanny" from the collection "The Secret of the Woman", 1974). Despite the fact that a single series of various portrait sketches of other characters harmoniously distinct and maximally juicy is lined up in the reader's field of vision, the writer remains constant in his appeal to the female image. Continuing the presentation in the form of a first person, on behalf of a certain young student, the narrator proceeds to reflection. He begins by not succeeding in erasing from memory his grandmother. The nanny helped the educated to acquire personal foundations, independent thinking, was there at any moment, but especially, gave him the mostneeded maternal love for him. Moreover, this line lasts to the last lines.

If we try to generalize, the role of women in family education, in the development of gender-based behavioral patterns, in the transfer of life experience between generations, and in influencing the formation of an individual complex of traits is undeniable. Carrying a mandatory pedagogical connotation, expressively affecting the educational effectiveness of the text, the image of a woman is diverse and multilateral. So, for example, the same Kh.I. Teuchezha in the 70 -s of the $20^{\text {th }}$ century. According to the plot, a couple of young people 
(the storyteller and his fellow student) who came to the city to study are looking for a rental house. In this way, they meet a Russian woman living among the Adyghe. In difficult times, she saved the owner of this house on the military field, in gratitude she remained to live with this family. Now she is a true nanny for their babies, a support in the household and really a member of the family. So, for example, the real nanny in the memoirs of F.M. Dostoevsky, who was recognized as a family member in his house: by her status, she was offered a salary, but she firmly refused it. The heroine, embodied by Maria Ivanovna, is a person who is both complex and mobile. Such a two-sidedness is reproduced wide open by an unusual means. The characters meeting her (and the reader with them) are conducting a persistent, gradual perception of the components of her character. Such may be wide, strange, new and sometimes sudden sides of her nature. The following appear to be similar: both moments of her bold participation in the war, and her courage, and elementary kind attitude to all living things, and personal impartiality, and much more like that.

This presentation is perceived as mandatory under socialist realism. This is the pompous reproduction of high duty and purity of service. However, there is also a rare sincere personality. In such a text, the elderly heroine, bright in her own, almost wild, simplicity, makes us wonder at the depths that are given to the service of people. A brave female character is outlined here. She could not stand the dishonor committed by her German soldier. This was enough to commit suicide. The narrator only draws what he saw from the outside, downplaying the cruelty and atrocities of those times. The writer reliably conveys what happened in mountain villages during the war years.

Moreover, in addition to the gender tendency emphasized in the portrait in the previous paragraph, thins inclination is also inherent in the ethical opposition obligatory in literature (good against evil). The problem of observing ethical standards of the behavior expected by society is also traced in the story. The narrative is a picture containing the psychology of an apostate forgetting about the spiritual norm. It should be emphasized that when covering such issues, Kh.I. Teuchezh does not always go directly. This happens through the sensations and reflexes of the heroine. There are her reflections on treason, her rejection of betrayal like any other anti-national catastrophe, breaking dogmas borrowed from her ancestors. The writer focuses on this. Thus, the focus here is on the spiritual and moral dominant, then mandatory elevation of heroism.

However, the same Kh.I. Teuchezh was able to reproduce (which was his purpose) the tragedy, catastrophic severity of the war period. It contained a surge of anger formed in the female heart. It was the contemptuous attitude of the heroine to the traitor, the grim contrast of the obligatory spaces located in the neighborhood - good and evil. Moreover, gender difficulties are manifested heterogeneous: men and women are not identical at all at the paralinguistic and speech levels of emotional tendencies (including negative), which are facilitated by certain facts. Moreover, in the global landscape, the concepts of "woman" and "man" are pivotal in various civilizations, in fact, harmonious constant phenomena of all kinds of cultures. Kh. I. Teuchez mainly attributes the constant to characters representing the military, which builds signs according to ethical signs, which was necessary in Soviet times as part of the nationwide "defense of the Soviet system".

Women could go beyond their gender roles. Perhaps because of this, one of the most characteristic and vivid phenomena of the 1960-80-s, and partly the 1990-s, was the development of the lyric novel genre in Russian literature. It most adequately corresponds to gender phenomena in literature (including Adyghe). Gender separation is successfully combined with the lyricism of this period. Against the background of increasing author's interest in the expression of characters, the dialectics of souls, the moral bases of the heroes' behavior, and possible internal conflicts are more extensively written out. Lyric works containing properties of the following genres are published: memoirs, prose poems, diary entries, travel notes, etc. One of the most adequate examples of this genre on a gender theme is the story of the Ka- 
bardian author A. Kushhaunov, "Southerner and Northerner" and "Flood", where the central characters of the plot are couples of lovers, in the description of which the storyteller's attention more often goes from a young man to a girl, to recreate her fragile, sometimes unrestrained, but sensitive and sincere inner world.

According to O.A. Dygova, when considering the prose of the second half of the last century, women's issues since the formation of written literature have been among the most involved and urgent. Both North Caucasian and Adyghe authors have written works on gender issues. "In our opinion, the most successful in the genre of the story is Ad. Shogentsukova "Spring Sofiyat" and P. Misakova "Pears are in bloom." The writers created complex, psychologically reliable female images, embodying the best aspirations of the "weak" but such a strong sex of Kabardian society "[2, p. nineteen]. This issue in conjunction with the analysis of the works takes place to be in the specified work, and therefore we will not carry out detailing now.

As for the means of expressiveness in portraying women, for example, M.M. Bakhtin quotes Panurgh from the book of F. Rabelais: "I see," he says, "that women are cheaper than stones in this city: walls should be built from female parts, and they should be placed in full architectural symmetry: put large ones in the front rows; further by lifting two slopes medium ones and, finally, small ones. Then, like a big tower in Bourges run through with the hardened swords inhabiting the monastic codpieces. What a devil will destroy such walls! " [1, p. 287]. Somewhat unconventional, but understandable for the French writer, the symbolic imagery of the grotesque. That is why indignation of M.M. Bakhtin frightens a little. As far as the modern French theoretician A. Companion is concerned, associations related to women, epithets and metaphors, personifications and comparisons are mentioned, structured and proved very actively and often. Therefore, for example, he manages to review and evaluate such a metaphorical form of deriving a female image as a "cat". Speaking about the opinion of the French philologist of the first half of the last century M. Riffater, he reproaches the opponent for the useless use of a "more dogmatic and more expensive wording", when "each poem explicates its own metaphors, so that the poetic passage cannot be metaphorical if it does not reveal to us explicit signs of metaphor"[6, p. 88]. A. Kompanion argues the thesis of futility as follows: "The result is the same:" Whatever the role of cats in the personal erotic imagery of the poet, it is not so important that because of this he instinctively writes "cat", wanting to say "woman" as we noticed, when he does this, he feels obligated to provide the reader with an explication "(Riffaterre, p. 359)" [6, p. 88]. By the way, a similar, "cat-like" metaphorical format was known and was already actively used by the critic of the 1930 -s of the $20^{\text {th }}$ century $A$. Grigoriev. He describes such a heroine, endowed with "cat-like" flexibility, as the embodiment of "graceful beauty, which never yields to completely gravitating over another, albeit beloved person" [3, p. 506], as one of the subspecies points in our classification of women, cited by us above.

Adyghe writers of the late 60s are no less active in addressing gender issues. The classics of that time A. Evtikh could not ignore it. His short story "The Story of a Woman" complies with the laws of the topic. The plot of the work is direct and elementary, and, according to the rules of lyricism, even simple. A woman is obliged to behave with dignity and not defiantly, she must be externally well-groomed in order to calm and make happy her fellow tribesmen. The central character of the plot is again gender. It is a young Adyghe heroine, brought up in a poor house of the mountain farmer, where, as is traditionally in the Adyghe society, girls up to maturity and boys till the age of 6 were brought up by women. The circle of activity of the child was built in this case, depending on the vital role and plans for the future. However, there was an elementary household routine. For example, housing care, not considered separately in scientific sources, or, for example, cooking. Inherent in women activities are reproduced by writers according to folklore (family songs) or personal, family experience. So, in particular, at Y. Tlyusten ("Girl's Dawns"), already at the beginning, a rider who ap- 
peared to be exhausted and frozen on the way suddenly finds himself in a family unknown to him, caring for and warming him. And it is imperative that in such a family a cheese and hot cakes are served to the guest for breakfast, from which the narrator concludes that the hostesses got up earlier than he did.

In addition, we mention such an aspect of activities as female inclination towards needlework, because. According to A.A. Bezrukova, quoting S. Siyukhov (Krasnodar, 1922), "in conditions of subsistence farming, the Adyghe, when choosing a bride, paid special attention to "the knowledge of needlework" [2, p. 131]. Or, for example, the middle of the $20^{\text {th }}$ century, Georgian novelist K. Gamsakhurdia, in his famous work "David the Builder", embroidery almost constantly accompanies the bride of King David and is one of her main activities as a positive personality indicator. Similarly, another example, in Y. Tlyusten ("Girl's Dawns"), the needlework complex of skills that invariably and often accompanies his heroines is constantly praised. One of them sews beautiful, hand-made hats for all interested mountain men; the other is a craftswoman in mats. However, the famous and successfully presenting Adyghe to this day, gold embroidery was the creative product of the aristocratic class of society. It may be too bright for the modern world, but these sweet and soul-taking, soothing mats, in our opinion, are no less professional.

Women took part in such important institutions of traditional Adyghe society as fosterage, hospitality and other life stages. So, the heroine of A. Evtykh, facing difficulties, does not resolve them personally, but agrees with everything that fate gives her. Suddenly, the moment expected by her and the reader comes up, drawn by the writer with the help of metaphorical expression: "She remembers the day when, like the sun, happiness came to her" [3, p. 5]. Love for work did not go unnoticed, and the girl earned a good reputation. A. Evtikh refused idealization and decided to show the negative side of society, which is rare for those times. We see a noble woman who finds herself in a difficult situation, and who cannot express her feelings and emotions. A member of the Adyghe society was not entitled to demonstrate their emotions, since in a large ethnic family such behaviors set and limited the boundaries within the couple, prohibiting any access to it from the outside. Similarly, the main character of $A$. Evtykh does not want to advertise her family difficulties, protects the family and covers her deceiving companion.

Just like spouses avoided fights and arguments, there was also ban on feelings towards children. This: "on the one hand, strictly limited the public and deliberate manifestation of feelings, and on the other, it did not allow physical punishment of children and discussion of their behavior with outsiders" [7, p. 27]. We can see that happen in the "Girl Dawns" by Y. Tlyusten. For example, the eldest woman in the family wove a beautiful mat, and the happy granddaughter at the same moment turned out to be next to her grandmother in order to express her joy. Here is how the author outlines the reaction of a strict woman in this case: "The old mistress liked the girl's praise, but she didn't give out her feelings, she said she was dissatisfied: "Go, go, do your business, you said too much already" [9, p. 25].

In general, as we note in our monograph in relation to the main character of A. Evtykh, "The strength of the spirit of the main character, her determination, combined with emotional softness and humanity are a harmonious fusion of precisely these qualities, their objective reflection in the story - this is what we call the character's artistic wholeness "[11, p. 81]. Nevertheless, the main factor here is not only the individuality of her partner, but also the new model of her own family. The main character tries her best to make everything in her house perfect and suit her companion's taste. Usually, even in childhood, the Adyghe tried to accustom girls to hard work, while explaining how to care for elders. Girls got used to work earlier than boys did, as they were sent with questions, parcels or tasks to neighbors, for water, etc. This is illustrated in his episode by Y.I. Tlyusten ("Girl Dawns"). Fifteen-year-old sisters set off, as usual, for water; but, when one of the young men decided to help them with buckets, they were very surprised. "They had not seen before that the Adyghe man carried water. Af- 
ter all, everyone knows that this is a women's work! " [9, p. 23]. In this work, we also observe the power of a woman in resolving conflict situations. For example, a woman with one wave of her handkerchief could stop a fight. Moreover, this particular factor as a component of the gender aspect in fiction can be considered a direct incentive in the process of forming ethnic consciousness for centuries.

Summing up, we can say that for all the current relevance and little study of the female image and gender component in prose, the available material can be considered sufficient and therefore the further prospect of research is well justified.

\section{Лumepamypa}

1. Бахтин М.М. Собрание сочинений в 7-ми томах, Т. 3, М.: Языки славянских культур, 2012, 880 c.

2. Безрукова А.А. Гендерные характеристики социальных позиций женщин в традиционном адыгском обществе // Вестник Адыгейского государственного университета. Майкоп: АГУ, 2011, № 1, С. 130-137.

3. Григорьев А. Литературная критика. М.: Художественная литература, 1967, 632 с.

4. Дыгова О.А. Художественно-эстетическое своеобразие повести в кабардинской литературе 1960 - 90-х годов: в контексте северокавказской прозы. Майкоп: Качество, 2008.

5. Евтых А.К. След человека. Майкоп: Адыгейское отделение Краснодарского книжного издательства, 1971, 397 с.

6. Компаньон А. Демон теории. М: Издательство им. Сабашниковых, 2001, 336 с.

7. Текуева М.А. Гендер как социокультурный конструкт адыгского общества. Махачкала, 2006.

8. Теучеж X. Сборник рассказов. Майкоп: Адыгейское отделение Краснодарского книжного издательства, 1974.

9. Тлюстен Ю.И. Избранное. Майкоп: Адыгейское республиканское книжное издательство, 1998, 608 с.

10. Ханаху P.A. Традиционная культура Северного Кавказа: вызовы времени (социально-философский анализ). Майкоп: Зихи, 1997, 194 с.

11. Хуако Ф.Н. Двадцатый век: эпоха и ее художественное отображение. Майкоп: МГТУ, 2012, $270 \mathrm{c.}$

12. Эйхенбаум Б.Н. О прозе. Л.: Художественная литература, 1969.

\section{References}

1. Bakhtin M.M. Sobraniye sochineniy v 7-mi tomakh. [Collected works in 7 volumes]. V. 3, Moskva: yazyki slavyanskikh kultur, 2012, 880 p. (In Russian).

2. Bezrukova A.A. Gendernyye kharakteristiki sotsialnykh pozitsiy zhenshchin $v$ traditsionnom adygskom obshchestve. Vestnik Adygeyskogo gosudarstvennogo universiteta. [Gender characteristics of the social positions of women in the traditional Adyghe society. Bulletin of the Adygea State University]. Maykop: ASU, 2011, No. 1, pp. 130137 (In Russian).

3. Grigoryev A. Literaturnaya kritika. [Literary criticism]. Moskva: Khudozhestvennaya literatura, 1967, 632 p. (In Russian).

4. Dygova O.A. Khudozhestvenno-esteticheskoye svoyeobraziye povesti $\vee$ kabardinskoy literature 1960 - 90-kh godov: v kontekste severokavkazskoy prozy. [The artistic and 
aesthetic originality of the story in Kabardian literature of the 1960s-90s: in the context of North Caucasian prose]. Maykop: Kachestvo, 2008 (In Russian).

5. Evtikh A.K. Sled cheloveka. [Trace of man]. Maykop, 1971, 397 p. (In Russian).

6. Kompanion A. Demon teorii. [Demon of a theory]. Moskva: Izdatelstvo im. Sabashnikovykh, 2001, 336 p. (In Russian).

7. Tekueva M.A. Gender kak sotsiokulturnyy konstrukt adygskogo obshchestva. [Gender as a sociocultural construct of the Adyghe society]. Makhachkala, 2006. (In Russian).

8. Teuchezh Kh. Sbornik rasskazov. [Storybook]. Maykop, 1974 (In Russian).

9. Tlyusten Y.I. Izbrannoye. [Selected writings]. Maykop, 1998, 608 p. (In Russian).

10. Khanakhu R.A. Traditsionnaya kultura Severnogo Kavkaza: vyzovy vremeni (sotsialno-filosofskiy analiz) [Traditional culture of the North Caucasus: challenges of the time (socio-philosophical analysis)]. Maykop: Zikhi, 1997, 194 p. (In Russian).

11. Khuako F.N. Dvadtsatyy vek: epokha i yeye khudozhestvennoye otobrazheniye. [Twentieth century: era and its artistic display]. Maykop: MGTU, 2012, 270 p. (In Russian).

12. Eichenbaum B.N. O proze. [About prose]. Leningrad: Khudozhestvennaya literatura, 1969 (In Russian). 